\title{
The Contribution of Syntax to Meaning
}

\author{
HANS ARNDT \\ Department of Linguistics, University of Aarhus, Denmark
}

Det indhold der ligger i en syntaktisk enhed, er et konglomerat. Om dette konglomerat skal ses som en 'sum' (kompositionel mening) eller et komplekst produkt, er et spørgsmål om metaforisk perspektiv. Jeg vil i denne artikel forsøge at isolere det bidrag som de syntaktiske relationer giver til det konglomerat vi kalder en sætning. Syntaks drejer sig om relationer. De simpleste relationer er 'subjekt-for', 'prædikat-for' og 'objekt-for'. De defineres ofte ved hjælp af kasusroller, men jeg vil argumentere for at subjekt-prædikat-relationen bedst forstås i lyset af tematisk struktur. Mere komplekse er de relationer der traditionelt kaldes 'indirekte-objekt' og 'prædikativ-til-objekt', og det er deres status der især er i fokus - min tese er at de ikke er selvstændige relationer, men subtyper af de simplere relationer. Eftersom skellet mellem de såkaldte oblikke argumenter og adverbialer ikke er ligetil, er det nødvendigt også at skitsere en typificering af adverbialer (der, parallelt med de øvrige relationer, kan kaldes 'adverbialer-for'). I artiklens første del defineres fire typer af 'betydning', forstået som den udtryks-indholdsrelation der ligger i ethvert tegn. I anden del giver jeg en oversigt over det syntaktiske tegns udtryksside. Den tredie og væsentligste del af artiklen omhandler indholdssiden i de syntaktiske relationer der er nævnt ovenfor. I den fjerde del behandles nogle analyseproblemer i sammenligning med traditionelle tilgange.

\section{MeAning ReLATIONS}

I shall take my point of departure in the meaning relation, i.e. the relation expressed by the terms expression and content - the relation which Saussure and Hjelmslev considered basic. However, this relation is far from simple. We may distinguish at least four different types of meaning relations.

1) Lexical meaning is the meaning that we may establish for words or morphemes in isolation - the type of meaning that dictionaries try to catch by enumerating near synonyms, and by paradigmatic contrast to antonyms, hyponyms, etc. Similarly, the meaning of morphemes is what grammars try to explain by contrasting members of grammatical paradigms, or by suggesting a prototypical meaning of a grammatical category such as present time for the present tense. The meaning of morphemes (or more generally of grammatical categories) is thus quite parallel to lexical meaning, and may indeed be seen as a subtype.

Alternatively lexical meaning may be explored in terms of components. Thus for instance the English word draw may be said to have a central component which, combined with 
various less stable components, gives the more specific complex meanings that we find in collocations like draw a cart, draw a sword, draw a sketch, draw blood, draw a conclusion, etc. The obvious difficulty with this alternative is to define the central component.

2) Collocational meaning, then, is the complex meaning that results when words or morphemes are combined with other words or morphemes, i.e. in a particular lexical context. Thus the specific complex meaning of draw in draw a cart (as opposed to draw a picture) etc, is a collocational meaning - a meaning that may be latent in draw itself, but is actualized in collocation (cf Togeby 1993: 221-228).

Lexemes are often said to be naturally ambiguous (partly because any central component may be extremely difficult to formulate), and by that approach lexemes can be said to be disambiguated by collocation. In that way what I have called lexical and collocational meanings are in effect collapsed in a two stage ascription of 'word meaning'.

3) Syntactic meaning is the meaning that results when words are combined in different constructions. For instance, it is the syntactic meaning that distinguishes He drew the reluctant horse back towards the stable from The reluctant horse drew him back towards the stable. The lexical and collocational meaning of draw (and all the other words) is the same in both cases. Similarly there is no lexical or collocational difference between The horse drew the cart and Did the horse draw the cart? The difference in content is a result of a difference in syntactic construction.

As with lexical meaning, one may posit a collocational variation for syntactic meaning (depending primarily on the choice of lexemes): peripheral content elements added to the central ones. This idea will will be developed further below (cf section 3.2).

4) Finally, utterance (or pragmatic) meaning is the meaning that results from the use that is made of a sentence in a particular situation(al context). Thus for instance when the train traveller remarks to a fellow traveller Very hot today, isn't it? he may mean 'Should we open a window?' or 'I am a bit embarrassed because I look so sweaty' or 'Shall we have a chat even though we don't know each other?' - and so on.

I shall concern myself here only with syntactic meaning. I have defined the others in order to delimit syntactic meaning. However, it may be pertinent to point out that the English word mean is (collocationally) ambiguous. This has had unfortunate consequences for the exploration of 'meaning' - and for semantics. In other languages, such as German and Danish and many others, we distinguish between two different 'meanings': 'Die Worte bedeuten/der Satz bedeutet ...' vs 'Der Sprecher meint ...'. Roughly, meaning 1-3 is Bedeutung (or linguistic meaning), whereas meaning 4 is Meinung (or speaker meaning).

\subsection{The expression of syntactic meaning}

Syntactic meaning may be explicitly expressed in four different ways. There is nothing special in the account I offer, but I hope my reader will bear with me: it is worth keeping in mind that syntactic expression is not a simple matter. 


\subsection{Word order}

Word order may be used to express various syntactic meanings. An English example:

1a) The boy didn't eat the apple.

2a) The apple the boy didn't eat.

3a) The apple didn't eat the boy.

4a) The apple the boy ate.

English makes sure that we understand what is the subject and what is the object by placing the subject just before the finite verb. (Example (3a) must be from a fairy tale - normally apples do not eat boys, but the syntax of (3a) forces us to consider this option.)

The interpretation of what is subject and object need not depend only on the place of the subject and the object. A Danish example (with the same meanings as the corresponding English examples):

1b) Drengen spiste ikke aeblet.

2b) Eblet spiste drengen ikke.

3b) Ablet spiste ikke drengen.

4b) Ablet spiste drengen.

\begin{tabular}{|c|c|c|c|c|c|}
\hline & $\mathrm{F}$ & $\mathrm{V}$ & $\mathrm{s}$ & $\mathrm{a}$ & $\mathrm{N}$ \\
\hline 1 & $\mathrm{~s}$ & $v$ & - & $a$ & $\mathrm{~N}$ \\
\hline 2 & $\mathrm{~N}$ & $v$ & $s$ & $a$ & - \\
\hline 3 & $s$ & $v$ & - & $a$ & $N$ \\
\hline 4 & $N$ & $v$ & $s$ & - & - \\
\hline$/ 4$ & $S$ & $v$ & - & - & $N$ \\
\hline
\end{tabular}

The difference between (2b) and (3b) is particularly informative: In (2b) oeblet is the object $(\mathrm{N})$, and in ( $3 \mathrm{~b})$ oeblet is the subject (the fairy tale example). The table to the right gives the explanation. Danish main clause syntax has a first or fronted position (F), followed by a finite verb (v), a subject (s), a nexus adverbial (a), and a secondary nominal $(\mathrm{N})$. (This is not the whole story, but enough for our present purposes; cf Diderichsen 1946.)

In (1b) and (3b) the subject is fronted (the default fronting). In (2b) the secondary nominal is fronted, and the position of the subject relative to the nexus adverbial leaves us in no doubt as to the interpretation of the construction. However, (4b) is ambiguous, because the lack of a nexus adverbial leaves us no way of determining whether interpretation 4 or interpretation / 4 in the table is the correct one. In other words (4b) can be disambiguated only by the wider context: whether (4b) belongs either (by analysis 4 ) in a normal situation (like 2 b) or (by analysis /4) in a fairy tale (like $3 b$ ).

\subsection{Particles}

By particles I shall understand both affixal morphemes (word particles) and clause particles (primarily adpositions, but also others, cf 4.3 below). ${ }^{1}$ A German example:

1c) Der Junge hat den Apfel nicht gegessen.

2c) Den Apfel hat der Junge nicht gegessen. 
3c) Der Apfel hat den Jungen nicht gegessen.

4c) Den Apfel hat der Junge gegessen.

In German the subject and the object simply change places from (1c) to (2c), thus word order does not affect the interpretation. But the case signals in the definite article ensure that the interpretation of what is the subject and object is unambiguous. (The position of the adverbial does not, at least in these examples, have any significance, cf $(3 \mathrm{c}-4 \mathrm{c})$.)

Two further examples show that case particles may be independent of definiteness signalling:

5) Schröder ham kender alle. N+pron-ACC /v /s-PL

6) Den Schröder kennen alle. ACC+N /v-PL /s-PL

In (5) an otherwise superfluous pronoun in the accusative has been inserted after the object nominal in fronted position, ensuring the object interpretation of Schröder ham. (This is not the whole story of the socalled double signalling in front position - thus the same doubling could occur in (4b): oeblet det, without any disambiguating effect, since det is not inflected for case.)

In (6) the definite article in front of Schröder has no obvious definiteness meaning, since names are born definite, but it helps signalling the object interpretation. Verbal concord in (6) is a further 'particle' signal of which nominal is the subject.

\subsection{Prosody}

Prosody is used mainly to signal syntactic delimitations:

7) Next year we shall meet, as we arranged at the meeting in Spain, in Aarhus.

8) Let's go and eat, Peter.

I have put in commas to suggest how prosody would be used to ensure the interpretation of (7) and (8). I can only appeal to my reader to try out the pronunciation of the two sentences. Without prosodic signalling (commas) (7) would seem meaningless or extremely difficult to interpret ${ }^{2}$, and in (8) prosody disambiguates between a vocative and an object reading of Peter.

\subsection{Elision}

The most obvious example of elision as a signal of syntactic construction is the elision of the subject in the imperative (9):

9) Have another cup.

10) I came to talk to you.

The meaning of elision in other cases, such as the elision of the subject in nonfinite clauses (10), is more difficult to explain, and I shall not complicate the present 
presentation with an attempt.

\subsection{Contextual cues}

The four types of signals I have included (word order, particles, prosody and elision) are what Hjelmslev called 'expression elements'. He used this term primarily about phonemes - elements that carry no meaning in themselves but are distinctive. The same holds for these syntactic signals: it is difficult if not impossible to pin a specific meaning on them outside the constructions in which they occur. Thus for instance the use of word order and prosody to signal interrogative constructions, has no obvious affinity with their use to delimit clauses or to identify subjects or objects. Particles may be different, but at least they are multiply ambiguous.

In order to complete the picture we have to add a further, implicit, means towards interpretation, i.e. contextual cues:

11a) Bankrøveriet var ikke nogen velplanlagt forbrydelse. Penge var der noesten ingen af $i$ kassen, og røverne fangede politiet ude på parkeringspladsen.

11b) Der Bankraub war kein wohlgeplantes Verbrechen. Geld gab es beinahe keines in der Kasse, und die Räuber haben die Polizisten auf dem Parkplatz gefangen.

In both the Danish and the German versions the underlined sequence is ambiguous (in the same way as (4b)). What ensures the ,correct' interpretation is partly that the first clause sets the stage, as it were, for an unsuccesful crime; and partly that we know that when any ,catching' is going on, the police is unlikely to be at the receiving end.

It is worth noting that in all of the examples (from (1) through (11)) there has been no lexical or collocational ambiguity: we are in no doubt as to the meaning of the words. Nor is there any question as to utterance meaning; even in (11) the contextual cues that we draw on, are not tied to a specific situation of utterance, but to our general lexical and world knowledge.

However there is an affinity between collocation and contextual cues. Collocation is what helps us pick a specific (latent) lexical meaning. Contextual cues have the same effect for both lexical and syntactic meaning, only over a wider scope of text.

\subsection{THE CONTENT OF SYNTACTIC CONSTRUCTIONS}

Like the expression side the content side is analysable in different elements. To begin with, however, it is necessary to distinguish between two different types of syntactic meaning: paradigmatic (or non-relational) and syntagmatic (or relational).

\subsection{Paradigmatic and syntagmatic meanings}

Paradigmatic syntactic meanings are those we find in the contrast between clause types. For instance, having established that a clause is interrogative (by means of $w h$-particles, and/or word order, and possibly prosody), we take this to have a certain meaning that is distinct from the meaning of a declarative clause in the same position in discourse. (This meaning relation is not simple, as I have shown in Arndt 1995.) 
The point is that the choice of a particular clause structure (such as declarative, interrogative, imperative, exclamative (What an enormous mouth you have!), existential (There is something in the air), and others) is a choice in a paradigm of clause types. This is not to say that the clauses are unrelated to the rest of the text or discourse, but their linguistic meaning is nevertheless that of a particular member of a paradigm, which is defined on the expression side by the elements mentioned above.

In the following I shall concentrate on clausal syntagmatic (i.e. relational) meanings, those of subject, object, and so on, whose expression have been partly illustrated in examples (1-6). With these there is no paradigmatic choice. Though the choice of a particular lexeme for, say, subject may influence the precise meaning of the construction, the point of working out the meaning contribution of syntax is to try to isolate the meaning of 'subject', regardless of lexical content. There are non-clausal syntagmatic relations (such as those of phrasal constructions), but they will not be described here.

\subsection{The subject-predicate relation}

The meaning of 'subject' is often described in terms of participant roles. Thus Van Valin and LaPolla (1997: 85-86) enumerate "commonly used participant roles in states of affairs", 13 in all, including such items as agent, patient, goal, location and path, mostly self-explanatory, except for "theme", which is defined as "things which are located or are undergoing a change of location".

On p. 115 they list an even larger number of "thematic relations in terms of logical structure positions" (29 in all) with names that are reminiscient of the terms for SoA (state-of-affairs, i.e. semantic content) roles, but also including some very specific terms, such as "wanter" and "desire" (for the subject and object of want) and "consumer" and "consumed" (for the subject and object of eat). Given that they are trying to chart the relations between verbs and their arguments, this may be seen as only a preliminary to the discussion of "the syntax-semantics interface" (ibid. p. 139), which is presumably comparable to what I have called syntactic meaning, i.e. the relation between syntactic expression and syntactic content.

In order to link SoA roles and verbal arguments with clausal roles Van Valin and LaPolla (pp. 139ff) introduce "the notion of semantic macroroles", which are "generalizations across the argument types found with particular verbs which have significant grammatical consequences". The macroroles are ACTOR and UNDERGOER, and these two subsume under them the various argument roles in a principled manner: they range the possible argument types in a hierarchy, and suggest a preferential assignment, such that roles at the upper end of the hierarchy (with agentive at the very top) are chosen for subject, whereas those below are chosen for object.

The way in which Van Valin and LaPolla link lexis, arguments and clause structure is illuminating. However the basis for this undertaking is lexical collocation, whereas I suggest that it must be possible to formulate a central syntactic meaning component, before including the peripheral ones depending on lexical collocation. 
There can be no doubt that such a central component will be very abstract. Consider the following list of sentences (I have indicated possible argument roles for the subject in the right hand column):
a. He made a bow and arrow.
agent
b. The sound frightened me.
cause
c. The sun is shining.
d. He died a horrible death.
source
e. He got a grammar book.
patient
f. He thrived on contradiction.
recipient
g. He heard it and thought about it.
beneficient
$\mathrm{h}$. The key opened the door.
experiencer
i. The bucket contains water.
instrument
j. Two hours passed.
location
time
$\mathrm{k}$. The car has no fenders.
possessor?
1. The car cost me 2000.
coster?
$\mathrm{m}$. The demonstration lasted an hour.
laster?
$\mathrm{n}$. The accident occurred yesterday.
occurrer?

However principled, the ranging of these roles in the hierarchy, as well as the assignment of participant macroroles to them, is a precarious process.

Instead it seems to me that the common denominator for the meaning of 'subject' must have to do with what we want to foreground as the topic or theme of the clause (and I feel much more comfortable with this sense of 'theme' than with the definition given by Van Valin and LaPolla, cf above). This becomes perhaps even clearer from the following set of examples:

13) a. He is the Demosthenes of the 20th century.

identified

b. He is an orator.

classified

c. He is eloquent.

described

$\mathrm{d}$. He is very much at home in front of an audience.

located?

e. He has a way with words.

possessor?

f. He speaks well.

agent

g. He really knows how to get across to people.

cognizer

The point of this set of examples is that they are roughly synonymous, even though the relation of the subject to the predicate may be taken to vary with the lexical verb (as indicated in the right hand column). In so far as they are not totally synonymous, the difference depends on collocation.

Hence my conclusion is that the central meaning of the subject is that of 'theme' (and in fact the term 'subject' suggests exactly that - 'subject' is originally a name for the content, not for the 'form', however much generations of grammarians have come to see the subject relation as a purely formal one; Van Valin and LaPolla's definition of theme (1997: 85-86, cf above) seems to be a derived and residual variant of this). I suspect that one reason for the reluctance to take this simple solution, is that 'information structure' (theme-rheme) is often assigned to pragmatics rather than grammar. ${ }^{3}$ 
This conclusion brings me back to the very origin of the grammatical terms: the subject is what the clause is about, and the predicate is what you say about the subject.

To come back to peripheral meaning: participant role is not irrelevant to the meaning of the subject. But I would see this as a function of speaker involvement: what we are interested in, is what people do and what happens to them. Therefore the typical participant for the theme/subject position is either agent or experiencer. But when we move outside the realm of people and their doings and experiences, as we do for instance in scientific or encyclopedic descriptions of the world, story-telling becomes at best a metaphor for the goings-on around us. ${ }^{4}$

The salience of agency in the subject would thus be a result of an 'unmarked' - originally perhaps most frequent - collocation of the subject with the type of verb that takes an agentive as its point of departure. This comes forward when we 're-interpret', as it were, common verbs which would naturally take another type of subject:

14) He got the car mended. recipient $>$ agent

15) She saw me home /saw to it that ... experiencer $>$ agent

On the other hand, there is nothing to prevent us from 'demoting' an agent from the subject position. For this purpose we have both grammatical (the passive) and lexical means, such as

16) He got a present from his uncle.

17) The road took us past the village.

18) I am to meet her at two $=>$ She is to meet me at two $=>$ We are to meet (each other) at two.

19) The car cost me $2000 \sim$ I spent/paid 2000 on/for the car.

20) The car has served me well I have driven it without problems.

In each of these sentences there are participants that could be put into an agentive position (ACTORS rather than UNDERGOERS, in Van Valins and LaPolla's terms), but which have been put into positions for secondary arguments or even adverbials. (18) is perhaps particularly illustrative, in that it contains two agents: $I / m e$ and she/her. What dictates the choice of subject in (18) is thematic structure, not SoA participation or verbal argument. $(17,20)$ illustrate the power of metaphor, (cf also note 4 ).

\subsection{The object relation}

As with the subject we may start by looking at a set of examples of possible argument roles for the object (indicated in the right-hand column):
a. I kicked him.
Patient
b. I told him about it.
Recipient
c. I built a house.
Result
d. I have a bicycle.
Possessee?
e. I saw him.
? 


\section{f. I know him. ? \\ g. I like him. ? \\ h. I drank him under the table. ?}

And as with the subject we find that the assignment of participant role to the object is extremely diffficult, in some cases wellnigh impossible. The object is a participant only in the sense of an extra 'involvee' - or an 'object' for whatever is the content of the verb (again 'object' is the age-old term for the content of the object, as was the case with the term 'subject'). In other words the object is a verb-to-object relation.

If we try to interpret this role more precisely, we find three types of peripheral and collocational meaning: With 'active' verbs (i.e. verbs that tend to take an agentive subject) the object may be either affected (as in 21a-b) or effected (or 'caused', as in 21c and $\mathrm{h}^{5}$ ); with 'mental' verbs (i.e. verbs that tend to take an experiencer subject) the object is simply unaffected - involved only as an experience (as in 21d-g).

\subsection{Subject predicatives}

Some 'objects' are of a very special kind, such as the second participants of verbs like cost, last, resemble. They are not passivizable (nor, in most cases, is have), but they do involve two different references, as is typically the case in transitive clauses (as the term 'transitive' implies). Verbs like cost, last, resemble seem to be borderline cases between objects and subject predicatives.

Subject predicatives are complements of verbs (typically be, become) which unload more of the ascriptive meaning of the predicate on the complement than do transitive verbs. Unlike typical transitive constructions such complements are not passivizable and mostly involve no other reference than the one given in the subject.

Subject predicatives are of several types: identifiers (if they are definite noun phrases, cf (13a)), classifiers (if indefinite noun phrases (13b)), descriptive (if adjectives (13c) or participles), or circumstances (if adverbials of time, place (13d), manner, etc). Circumstantial ones are the least obvious, partly because they (like cost, last, resemble) often do involve an extra reference, and they are mostly classified as 'obligatory adverbials'.

However, from a syntactic and semantic point of view their affinity with typical subject predicatives seems more striking than the dissimilarity. Consider the following examples:

22) He is absent / abroad / in England.

23) He is a londoner / from London.

My point here is that if absent and a londoner are subject predicatives, then there is every reason to say that so are abroad, in England and from London (in syntactically and semantically parallel structures). The same holds for the socalled object predicatives (which I shall come back to presently): 
Again there seems little difference in the syntactic meaning of constructions like him ready and him awake/up/out of bed (cf further 4.1. below).

It may be worth pointing out that the origin of 'predicative adjectives' like abroad and alive is a prepositional phrase, as is the origin of the 'adverbs' away, abed, afoot - which naturally occur in predicative positions (such as They were early afoot).

To sum up so far, the relational content of the subject-predicate is the simple one of, well, subject and predicate. The predicate (i.e. what is predicated about the subject) in its turn may be simple (with intransitive verbs, disregarding for the time being adverbial elements) or complemented. The complement may be either an object, which is a secondary referent (where the subject is the primary referent) which may be affected, effected or unaffected by the content of the verb; or a subject predicative which is typically descriptive rather than referential.

\subsection{Secondary predications}

It is customary to reckon with two more independent elements in the clausal structure: indirect object and object predicative. But there is not generally agreement as to where to draw the line between these and adverbials, or as the problem is often formulated: between 'arguments', 'oblique arguments' and adverbials.

My claim for indirect objects, object predicatives and also accusative+infinitive is that they may all be explained as secondary predications. With accusative-with-infinitive this is probably the commonest analysis. In the following examples the content of the secondary predication is indicated in the right-hand column:
a. I persuaded
them to stay
state
b. That started
me running
activity
c. She got
me to fetch a drink
d. I helped
him understand
cognition
e. I'll let
you know
f. He made
them like him
valuation
g. I'll force
you to talk
utterance

In all these examples the finite verb is followed, not by a simple object, but by a secondary predication which fills the role of object, in fact an effected object, in that the secondary predication is the result of whatever action is indicated by the finite (primary) verb (with an agentive or causative subject).

There is one example that does not fit the description accusative-with-infinitive, namely (25b), which is an 'accusative-with-gerund'; and the infinitive examples vary between needing or dispensing with the infinitive marker $t$. It is possible to formulate tentative rules for the typical distribution of these forms, but the choice depends mainly on the finite verb, i.e. it is idiomatic, determined by the lexeme. Common to all is the 
predicative relation between accusative and non-finite verb.

Some of the finite verbs indicate only causation (such as make, get), whereas others have other content as well, but they are all what I have called 'active' verbs. In a few of the examples (25d, g) the accusative might function as an object in itself, but mostly the object must necessarily be the unit of accusative and non-finite (typically with get and make).

The content of the secondary predication, on the other hand, may vary considerably, as indicated in the righthand column. This holds also for the examples in $(26,27)$.
a. He made
her happy
description
b. They built
the house bigger
c. They painted
it green
d. She made
him a man
classification
e. They elected
me (as) the leader
identity
f. They ran
him out of town
location
g. I sent
him to Timbuktoo

The examples in (26) show the construction traditionally referred to as direct object + object predicative. As in (25) the finite verbs are all causative (though some have other content as well), and the content of the secondary predication varies. (26f, g) are perhaps special in that they contain locatives (traditionally analyzed as 'obligatory adverbials') as 'object predicatives' (but cf the argument in 3.4 above and 4.1 below).

(27) shows the same analysis for what is traditionally called 'indirect object + direct object':

$\begin{array}{lll}\text { a. She baked } & \text { him a cake } & \text { possession } \\ \text { b. They sent } & \text { him a gift } & \\ \text { c. I provide } & \text { them with food } & \\ \text { d. He helped } & \text { himself to a drink } & \\ \text { e. I'll play } & \text { you a tune } & \text { perception } \\ \text { f. He showed } & \text { me the drawings } & \end{array}$

Again we have active finite verbs with effected secondary predications. The content of the secondary predications seems to vary less than in $(25,26)$ above, but on the other hand 'possession' is rather a ragbag of different contents.

So much for the effected predicational objects of causative verbs. With 'mental' verbs (i.e. verbs of cognition, valuation and perception) the predicational object is unaffected (as are simple objects with mental verbs). Examples:
a. I expected
them to sleep
ACC+INF: state
b. They expected
me to run
activity
c. She wanted
me to fetch a drink
d. I'd like
you to listen
activity
perception 

e. I want
you to know
f. He suspected
them to dislike him
g. I heard
you talking
cognition
valuation
utterance

29)
a. He considered
b. They wanted
c. She regarded
d. They knew
e. I took
f. They wished

her happy

the house bigger

him as a man

him to be the leader

you for someone else

him out of town

30)
DO+OP: description

classification

identity

location

IO+DO: possession?

The analysis of the clauses with mental verbs (28-30) is similar to the one of clauses with active verbs (25-27), though the range of examples with $\mathrm{IO}+\mathrm{DO}$ seems to be more restricted after mental verbs.

However there is one major difference: you cannot cause anything to happen by expecting, hearing or wishing. In examples (28-30) the secondary predication is not caused by the primary predication, it is modalized; either epistemic (as in 28a and 29a) or deontic (as in 28d and 30). Examples (28-30) can be interpreted to say that if the cognition/valuation/perception of the primary predication bears out, the $\mathrm{n}$ the secondary predication holds. E.g. I shall have a safe journey if his wish comes true (30a).

On the other hand, the examples of causal structures (with effected predicational object, 25-27) can be interpreted to say that the secondary predication holds b e c a u s of the primary predication. E.g. He is in Timbuktoo because of what I did (26g).

It should be added that the primary verb that governs the secondary predication may contain a negative content element whose domain is the secondary predication, e.g. rob $s b$ of sth, prevent $s b$ from doing sth, cost $s b$ sth, forbid $s b$ to do sth.

To sum up so far, complex complementation is predicational. The first complement is the subject of the secondary predication, and the second complement is its predicate. The secondary predication may take three forms (customarily called acc+non-finite, indirect object + direct object, and direct object + object predicative). The content of the primary verb (the primary predication) is roughly to indicate either the cause (active verbs) or the modality (mental verbs) of the secondary predication.

The predicate of the secondary predication, particularly a prepositional phrase following a 'direct object', is often analyzed as an adverbial clause element. However it seems that this distinction is based on the form of the element, rather than its function, cf 3.4, 3.6, and 4.3 .

If there is a direct object in the secondary predication, it bears the same relation to its verb as does any direct object. 


\subsection{Adverbial relations}

Adverbials in the clause are of several types, and I cannot treat them exhaustively here. But I need to outline the most obviously distinct types. The expression signal that typically distinguishes them in English, is word order and prepositions, and the major positions in the clause are three: Fronted, nexal (i.e. next to the finite verb) and final.

I should add that adverbials are an unruly lot, and a classification according to expression does not always coincide precisely with a classification according to relational content. Nevertheless they tend to fall in the following relational types:

Adverbial to $\mathrm{V} /$ predicate

31) He ate bananas normally. 'in a normal manner'

Position(s): -fronted; -nexal; +final

Manner adverbials typically modify the verb or the predicate as a whole, thus becoming part of the predicate.

\section{Adverbial to Clause/predication}

He ate bananas for hours. '... that took place for hours'

Position(s): +fronted; ?nexal; +final

This type provides a frame or setting for the predication in which it occurs (McGregor 1997), and it includes time (point and period), place, cause, and condition adverbials.

33) He normally ate bananas.

'it was normally the case that ...'

Position: +fronted; +nexal; -final

This type includes modal, degree, and frequency adverbials, which are generally qualifications of the validity of the predication.

34) I also gave Peter a book.

+nexal position; other positions prosodically marked

Focus adverbials may focus either on the predication as a whole, or, more usually, on the predicate (e.g. It is true that I came late for the party, but I also gave Peter a book).

However, a focus adverbial may also (prosodically or by word order) single out a particular other element, either a nominal or another adverbial:

- Focal

35) I gave also Peter a book (also I gave...; gave him also a book)

Position according to focus, usually prosodically marked.

Adverbial focus on individual elements is the first in a number of constructions that may be considered adverbial from one point of view, but seem also to have modifying or predicative properties. ${ }^{6}$ The fact that they may relate also to a particular other element 
in the clause, is what makes adverbials especially flexible. The simplest example is the type of focus just mentioned, but there are others.

Adverbial to Nominal (or other individual clause element)

Subject adjuncts are adverbials that "characterize the referent of the subject with respect to the process or state denoted by the verb" (Quirk et al. 1972), such as (36):

36) Clumsily he moved the bag into the aisle. subject adverbial, typically fronted

37) He moved the bag clumsily. manner adverbial, typically final

It might be assumed that (36) was an example of a manner adverbial, but the difference in content should be clear. (36) means 'it was clumsy of him to move ...', whereas (37) means '... moved it in a clumsy manner'.

Socalled 'free predicates' differ from subject adverbials in that they are not morphologically signalled as adverbs, but are otherwise similar in that while they cannot reasonably be considered as arguments of the verb, they nevertheless characterize nominal arguments; and their positions are either fronted or final. They may characterize either subject (38) or object (39).

38) Almost desparate, we finally found him by the pond.

39) We found him by the pond, wet and despondent.

Free predicates might also be considered free modifiers, displaced and parenthetic. The following, however, illustrate a difference between modifiers and predicates:

40) I caught him stealing.

41) I caught him in the act.

'I caught him as he was ...'

42) I saw him behind his desk.

43) I saw the man from the tower.

$(40,41)$ could be construed as postmodifiers. However there is also something of the secondary predication in them - it is not just 'I caught him who was stealing', rather it is 'I caught him as he was stealing'. In fact, though 'I caught him' is a natural inference from $(40,41)$, it is not a necessary entailment - the necessary entailment is 'I found out that he was stealing', which brings it close to the content of the type of structure illustrated in (28-30).

(42) seems more straightforwardly adverbial: the circumstantial type (cf 32). But a moment's reflection shows that it cannot be parallel - it is unreasonable to transscribe it in the same way as (32) to 'I saw him, and that took place behind his desk'. In other words (42) represents a hybrid between a circumstantial adverbial interpretation (32) and a secondary predicative one (cf 28-30).

Finally, (43) shows the wellknown ambiguity between a postmodifier interpretation ('it was the man from the tower I saw') and a circumstantial (or possibly manner) adverbial 
('it was from the tower I saw the man').

On the background of this structural flexibility of what we are used to calling simply adverbials, it is perhaps easier to accept the variety of predicates I have postulated for the secondary predications above.

\subsection{VARIOUS ANALYTICAL PROBLEMS}

There are at least three loose ends in the analysis I have presented so far. One is the assignment of secondary predicate status to adverbs and prepositional phrases. The second is thematization: if the content of the subject is 'theme', what about other - nonsubject - themes? The third is the status of prepositions (and other clause particles) which are preposed to objects or placed between secondary subject and predicate.

\subsection{In support of the secondary predication analysis}

In the following examples I shall juxtapose traditional predicative with untraditional ones.

Constructions like We got him to leave is what would be called accusative + infinitive, and presumably the one that is most readily accepted as a secondary predication. And again the syntactic similarity to got him out/ready is much more salient than the dissimilarity, which consists only in the lexical material (e.g. adverb) or the internal structure (e.g. prepostional phrase, cf 3.4).

Then there is the question of analyzing not only accusative-with-infinitive, but also object+object-predicative and indirect-object+direct-object as secondary (object) predications. Consider the following:

44) The cold gave him a fever $=>$ He has a fever

45) The cold made him feverish $\Rightarrow>$ He is feverish

46) He showed me the buildings $\sim$ He made me see the buildings

(44) and (45) show the affinity between the secondary predication and a corresponding finite predication (with have and be respectively). The parallel between the IO+DO and the acc+inf constructions is shown in (46). The reduced meaning of have (not possession, but predicative relation) is found in a number of collocations, as is also shown by the parallel between (44) and (45). ${ }^{7}$

The evidence I have presented so far has been mainly based on the semantic similarity of syntactic constructions which look superficially different. In other words on the syntactic meaning relation between the elements in question. Two more formal phenomena may be adduced.

In languages that have a distinct reflexive pronoun (such as Danish), which naturally refers to the subject of the clause in which it occurs, it is not uncommon for reflexives to refer to what I have called the subject of the secondary predication. 
47) Loereren bad Brian gå tilbage til sin plads. ('the teacher told Brian to go back to his place') (Acc+inf)

48) Irak har givet proesidenten problemer $i$ sit bagland. ('Irak has given the president problems with his supporters') (IO:DO)

49) Arven gjorde ham til sin egen herre. ('The inheritance made him his own master') (DO:OP)

In all three examples the possessive reflexive refers within the secondary predication. I should add that this is not necessarily so. An example like Loereren bad Brian hente sin taske ('the teacher told Brian to fetch his bag') is ambiguous (as is the English translation), disambiguated only by contextual cues. However the fact that reflexive reference within the secondary predication is at all possible, shows that this construction is not just my postulate.

Finally, secondary predications seem to be necessary for the analysis of certain complex adverbials, i.e. they are not needed only to explain the object constructions.

50) He came in with his hands in his pockets.

51) He stood with his hands up.

52) He left the bathroom with the water running. (with the running water)

Clearly in $(50,51)$ the phrases with his hands, in his pockets and up are not independent adverbials in the clauses. Nor can we analyze the relationship between them as modification - (52) in particular is illustrative in that the natural position for an adjectival modifier would be before its head. This is not just 'free variation' as the alternative in brackets shows.

The upshot is that secondary predications (with or without a verb) seems to be a natural analytic solution to the question of the meaning relation between otherwise troublesome elements.

\subsection{Thematization}

I mentioned above that the most typical (though not invarious) choice of argument for subject/theme is an agent. There are three ways to avoid this.

First, certain verbs are construed in their lexical configuration in a way that demands a non-agentive subject (cf examples 16 and 19), even if there is an agent available in the SoA and in the clause. And of course clauses that have no such agent must take another kind of subject, such as in examples (28-30) with the finite verbs of perception, valuation and cognition. This follows from the semantics of argument structure, as well as metaphorical use (cf 17, 20).

Secondly, we have the paradigmatic choice of passive rather than active, which fits well with the construal of the subject as theme, because it favours the choice of an alternative subject/theme, regardless of the type the predicate would 'prefer' (it is worth noting that the non-agentive subjects of $(18,20)$ can be demoted in a passive construction if another theme is chosen - this holds for most mental verbs as well, cf (28-30), though 
not for examples 16, 17, 19).

In many cases the passive shades into a one-argument attributive predication, such as in The shop is closed vs The shop is open. In other cases the choice is clearly thematic, as in I was surprised by his question or Though late for the reception, he was received effusively by the mayor.

Thirdly, and most problematically, there is the introduction of a theme which may be marked by word order or particle, but does not take the subject function. The only way to explain this is by suggesting two types of themes: a default one, which is the subject, and whose status is thus formalized; and a more flexible marked theme, which is typically an adverbial (as is most often the case in English, cf Lyons 1977: 506) but may also be an argument (as is often the case in Danish and German). Examples:

53) (Can you come Sunday morning?) - On Sunday morning I go to church!

54) Den kenne ich nicht. / Ham kender jeg ikke. / Him I don't know.

It is perhaps possible to understand (53) in terms of chinese boxes: in the inner box I go to church is a predication in its own right, with $I$ as the theme; in the outer box we have larger predication, whose theme is On Sunday morning and whose predicate is the inner predication I go to church. But I am aware that this may be seen as a frivolous use of terminology - which would perhaps be rather more difficult to apply to (54).

At any rate the idea of multiple themes is not new, cf Halliday (1985: 53ff). Halliday however makes a sharp distinction between subject and theme. He stresses the particular relationship between subject and finite verb, signalled by concord and highlighted in tags, and accepts it as thematic only if there is no other, marked, theme. It seems to me, though, that this structural description of the subject evades the question of defining the specific function of the subject. Hence my distinction between a formal (default) and a marked theme. And the reason for the retention of the default theme, rather than a passivization (which would be grammatically possible in (54)), is the saliency of the referent in the agent (or experiencer) role (cf 3.2).

Halliday (1985: 49ff) also suggests various extraclausal elements as interpersonal or textual themes, such as vocative expressions, or conjunctives (conjunctions like but, when, and conjunctive adverbials like however, then). I think it is important to include a consideration of these elements, not least because they are prominent in the spoken language. On the other hand I prefer to analyze the clause as a unit in itself, and to see those specific interpersonal and textual elements as extraclausal utterance phenomena, which are structurally peripheral (even though conjunctive adverbials may be found in adverbial positions in the clause, as well as in typical thematic front positions).

Part of the inspiration for a separation of subject and theme comes from languages like Latin and Russian, which rely more on case signals, and can thus use word order more freely to signal marked theme. It is arguable that these languages require a different definition of clause elements. If we go further afield, languages like Japanese and Tagalog use distinct particles to signal thematic and argument roles. Despite the superficial 
similarity between Indo-European languages, there is no reason to believe that their subject and theme definitions are typologically identical.

\subsection{Clause particles}

Clause particles are often taken to be important for the distinction between arguments and adverbials. Thus in sentences like He sent the book to Peter the use of to (and the placement of the recipient at the end) is supposed to signal that that the indirect object has been 'demoted' from 'secondary involvee' (object) to adverbial.

In my analysis the difference would be minimal, as I believe it is to most users of English: a matter of how we see the secondary predication. If the IO+DO (Peter the book) construction is chosen, the implication is 'so now he has it'. If the locative DO+OP (the book to Peter) construction is chosen, the implication is 'so now it is with him'. Only in very few cases would there be a difference between a 'gift' interpretation and a 'location' interpretation.

A similar case is the wellknown type load the wagon with sand - load the sand on a wagon - both analysable as DO+OP. It seems that the difference may be explicable as a difference in the choice of subject/theme for the secondary predication. The particles ensure that this syntactic difference does not lead to a difference in the implications of the sentence, giving only a difference in thematic meaning. At the bottom of it is the collocational meaning difference between load a wagon and load sand.

Otherwise I believe that the introduction of clause particles is generally to be explained in terms of collocation and idiom rather than syntactic structure. One piece of evidence for this is word formations like put sb off - be offputting, stand out - be outstanding, come out - the outcome. Admittedly the connection is often semantically tenuous, such as come in - income, go out - outgoing, but this is due to the diachronic nature of word formation: once formed, a new word develops its own meaning. ${ }^{8}$

Moreover, phrasal verbs like look at, look for, think about correspond semantically roughly to watch, seek, consider. The prepositional markers have been attached to these verbs in the development of the language, presumably through a change from intransitive to transitive use. Similarly, verb-adverb incorporates, such as go away $(\approx$ leave), give in $(\approx$ surrender) seem readily explicable as idioms. When such constructions are transitive, such as send away and throw out ( $\approx$ expel) the interpretation of the particle vacillates between secondary predicative (I sent him away $=>$ he is away, I threw it out $=>$ it is out) and true incorporate to the verb (I looked it $u p \neq>$ it is $u p$ ). In both cases the particle is placed before the 'object' if this is not a pronoun.

Occasionally we find verb-adverb incorporates where the 'particle' is a prepositional phrase, and in such cases movement of the particle is rare: We took the car we had stolen to pieces $=>$ is is now in pieces. Here the secondary predication analysis seems entirely natural (obviously with a special collocational meaning for take).

Perhaps the idiomatic nature of the particles comes out most clearly in cases where they are not clearly incorporated, nor prepositional, i.e. in cases where they act as a 
predicational link in secondary predications:

$\begin{array}{llll}55) & \text { (I regard) } & \text { him as a natural leader } & \text { ('he is a natural leader') } \\ 56) & \text { (She took) } & \text { me for someone else } & \text { ('I was someone else') } \\ 57) & \text { (She turned) } & \text { him into a toad } & \text { ('he became a toad') } \\ 58) & \text { (They provide) } & \text { me with food } & \text { ('I have food') } \\ 59) & \text { (They delivered) } & \text { the food to me } & \text { ('the food is with me') }\end{array}$

The introduction of as in (55) can hardly be taken as a signal that this construction is different from, say, I consider him a natural leader. It is just that certain verbs require a link in the secondary predication they are followed by. This is not to say that we cannot find a good explanation in the semantic diachrony of these combinations. But synchronically the content contribution of, say, for in (56) is a far cry from its content value in She brought a book for someone else.

Altogether clause particles are the coolies of syntactic construction and language development. Whenever there is a special relation or a special collocation to be established, particles are exploited for any odd job.

\section{CONCLUSION}

The account of clause structure I have given, is an attempt at simplification. This is not to say that clause structure is simple (I freely admit that there are lots of loose ends and untouched topics).

What I have attained, is, first, an account of transitivity that reduces the complexities created by the attempt to account for numerous participant roles in terms of clause structure and extra complements, signalled by case or clause particles. In my analysis we have two transitivity elements, the subject, which is the theme (or indeed the 'subject') of the predicate, and the object, which is related to the verb as a secondary involvee (indeed as 'object' of the verb); the object, in its turn, may be simple, or predicational (a non-finite, often verbless, secondary predication consisting of subject and predicate). In the process, many particles have been reduced to signals on the expression side, with no independent content value.

Participants and particles are still important in structure, but their introduction in the clause depends on lexical and collocational meaning and idiom (diachronically explicable, but synchronically often idiosyncratic), not primarily clause structure.

Secondly, it has been assumed throughout my presentation that syntax is meaningful, and that the various elements of clause structure are signs, whose content - abstract though it is - can be defined. And the definitions I have offered, are in terms of relations between clause elements, rather than in terms of clause-external values. Even if my analysis should be found insufficient or inadequate, I find the enterprise important, because I believe that any attempt to find universals of clause structure must be based on the content side, not on expression.

This is also my defence for the very limited set of languages I have exemplified from. 
They are languages in which we can establish fairly clearly what functions reside in subjects, objects, and adverbials, etc. And only on this basis can we determine whether these terms are applicable to typologically different languages.

\section{REFERENCES}

Arndt, Hans (1995), "What's in a Question?", in: Millar, Sharon, Jacob Mey (eds.) (1995), Form and Function in Language, Odense: Odense University Press, pp. 99-116.

Diderichsen, Paul (1946), Elementoer dansk grammatik, København: Gyldendal.

Halliday, M. A. K. (1985), An Introduction to Functional Grammar, London: Arnold.

Lyons, John (1977), Semantics, Cambridge: Cambridge University Press.

McGregor, William (1997), Semiotic Grammar, Oxford: Oxford University Press.

Quirk, Randolph, Sidney Greenbaum, Geoffrey Leech, Jan Svartvik (1972), A Grammar of Contemporary English, London: Longman.

Togeby, Ole (1993), Praxt: Pragmatisk tekstteori, Århus: Aarhus Universitetsforlag.

Van Valin, Robert D., Randy LaPolla (1997), Syntax: Structure, meaning and function, Cambridge: Cambridge University Press.

\section{NOTES}

1 Studies of grammaticalization have shown that the difference between affixal and clausal particles is not absolute.

2 In fact it is possible to interpret (7) without a break, as there happens to be a street in Århus called Spanien.

3 But lots of grammatical categories have pragmatic effects (in the sense that they signal speaker involvement with his utterances); and I doubt that anyone would suggest that the pragmatic meaning of, say, tense and modality puts these outside the domain of grammar. From a functional point of view pragmatic effects of grammatical categories is entirely expectable.

4 Cf the following quote from Stephen W. Hawking A Brief History of Time: "General relativity theory predicts that heavy objects that are moving will cause the emission of gravitational waves, ripples in the curvature of space that travel at the speed of light." (1989: 94)

5 (21h) is explicable only in terms of the analysis given below in 3.5: there is no direct syntagmatic meaning relation between the verb and the 'object' him.

6 In some of these cases one might speculate that there are constructions which are semantically unambiguous but analytically ambiguous - an interesting idea, which however I shall not pursue here, cf. ex. (42).

7 Further exidence of this kind of reduction can be found in Danish examples like Han har travlt ('he is busy', literally 'he has busily' - travlt is an adverbial form). And it is perhaps not too far-fetched to suggest also that the perfective auxiliary have is related to the simple predicative, rather than to the 'possession' meaning of have, as shown in the vacillation between He is gone and He has gone.

8 In German the connection is grammaticalized as socalled 'trennbare Verben', such as in Ich warf ihn hinaus - ich habe ihn hinausgeworfen. 